\title{
Tropical Soda Apple Leaf Beetle, Gratiana boliviana Spaeth (Insecta: Coleoptera: Chrysomelidae: (assidinae) ${ }^{1}$
}

\author{
Rodrigo Diaz, William A. Overholt, Ken Hibbard, and Julio Medal²
}

\section{Introduction}

Tropical soda apple, Solanum viarum Dunal (Solanaceae), is a prickly shrub native to South America. First reported in Glades Co., Florida in 1988, tropical soda apple later spread to Georgia, Alabama, Louisiana, Texas, Mississippi, Tennessee, North Carolina, and South Carolina. It is a major problem in pastures and conservation areas. Negative impacts of tropical soda apple include reduction of cattle stocking rates, competition with native plants, and the costs associated with its control (application of herbicides and mowing). Additionally, dense thickets of the weed may disrupt the movement of wildlife.

The tropical soda apple leaf beetle, Gratiana boliviana Spaeth, was discovered in Paraguay and imported into the United States to study its potential as a biological control agent. Because Gratiana boliviana fed and survived only on tropical soda apple, field release was approved in 2003. A multi-agency program supported the rearing, distribution, and release of more than 250,000 beetles across Florida from 2003 to 2011. Gratiana boliviana was also released in Texas, Alabama, and Georgia, but establishment has not been confirmed.

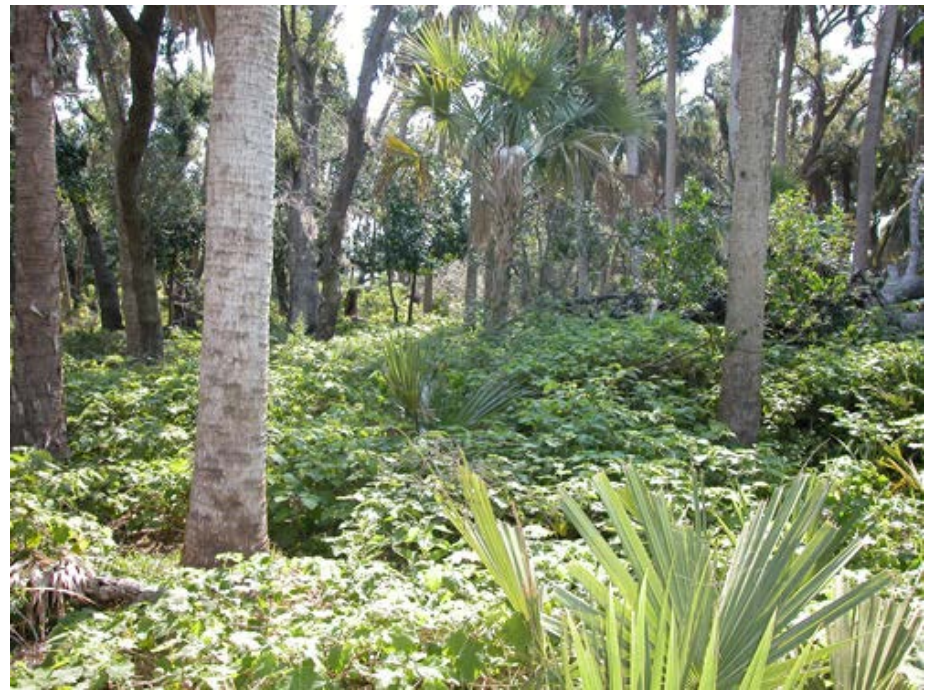

Figure 1. Tropical soda apple infestation in St. Lucie Co., Florida. April 2006. Credit: William A. Overholt, University of Florida.

\section{Distribution}

Gratiana boliviana is native to southern Brazil, northern Argentina, and Paraguay. In Florida, the beetle is present throughout much of the state. However, field surveys have shown that the damage to tropical soda apple by Gratiana boliviana is most evident in areas below $29^{\circ} \mathrm{N}$ latitude (approximately the latitude of Wildwood, Florida).

1. This document is EENY-543, one of a series of the Entomology and Nematology Department, Florida Cooperative Extension Service, Institute of Food and Agricultural Sciences, University of Florida. Original publication date January 2013. Visit the EDIS website at http://edis.ifas.ufl.edu.

2. Rodrigo Diaz and William A. Overholt, Indian River Research and Education Center, Entomology and Nematology Department, Institute of Food and Agricultural Sciences, University of Florida; and Ken Hibbard and Julio Medal, Florida Department of Agriculture and Consumer Services. 


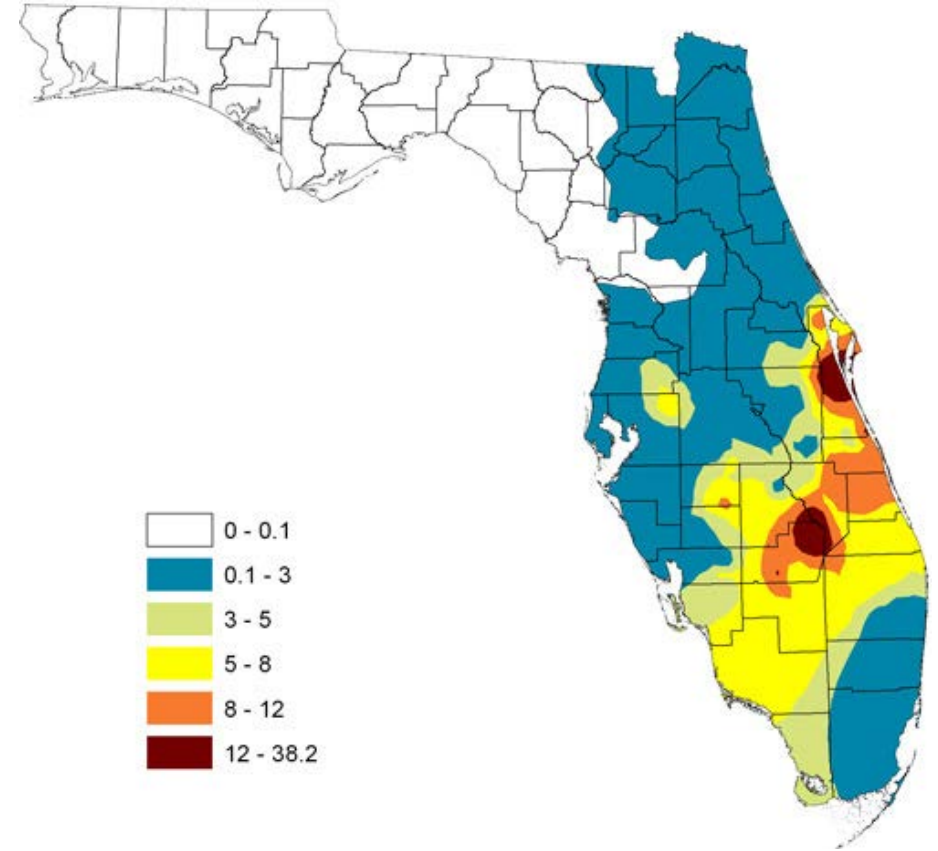

Figure 2. Density of Gratiana boliviana per plant during 2008 and 2010 in Florida. Credit: Rodrigo Diaz, University of Florida.

\section{Description}

\section{Eggs}

The eggs are 1 to $1.8 \mathrm{~mm}$ long, brown and enclosed in a papery envelope.

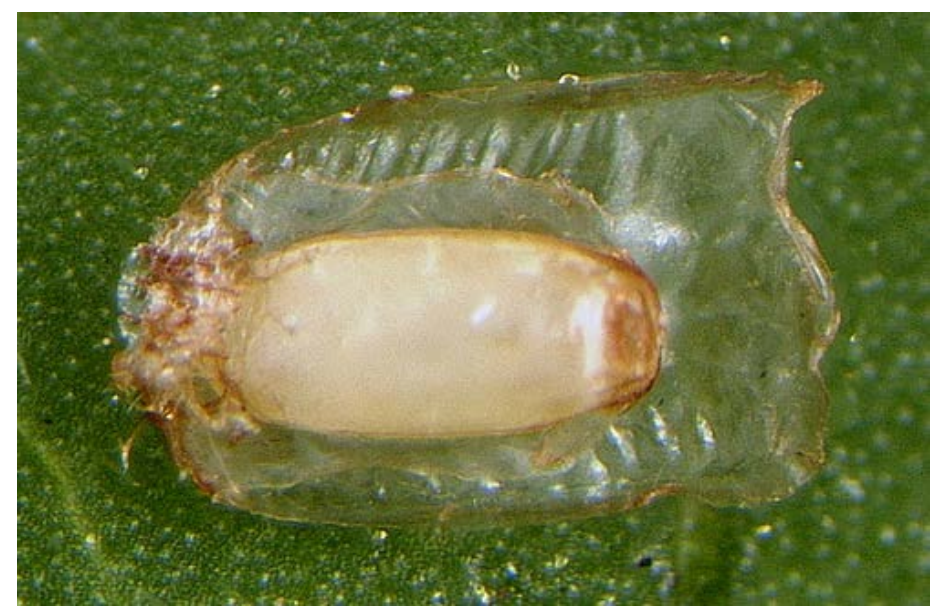

Figure 3. Egg of Gratiana boliviana. Credit: Rodrigo Diaz, University of Florida.

\section{Larvae}

The larvae are pale green and spiny. Later instars can be recognized by the presence of cast skins and frass that they carry as camouflage on their backs.

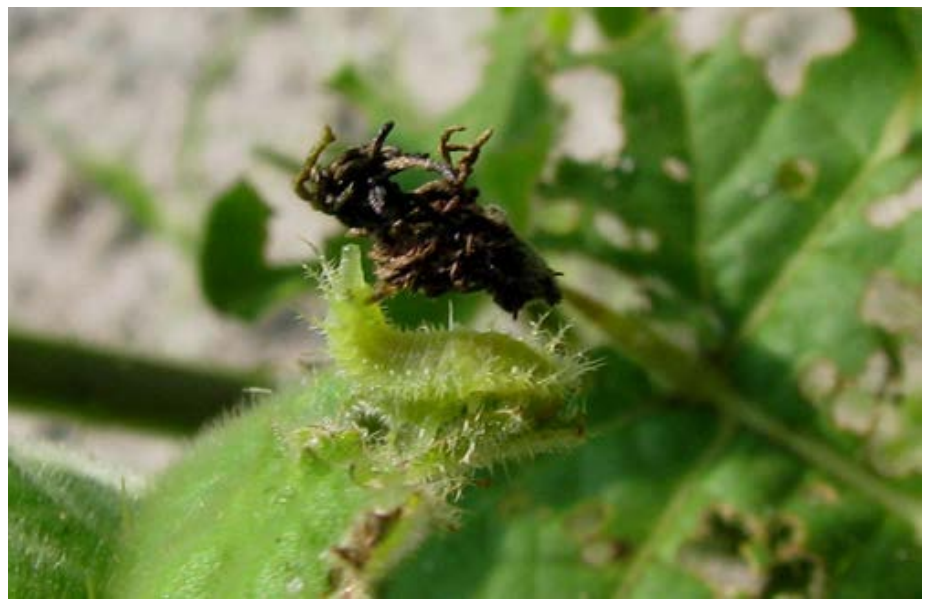

Figure 4. Larva of Gratiana boliviana; note frass and cast skin. Credit: Rodrigo Diaz, University of Florida.

\section{Pupae}

The pupae are 5 to $6 \mathrm{~mm}$ long, pale green, spiny, flattened and immobile. Pupae are found on the underside of leaves.

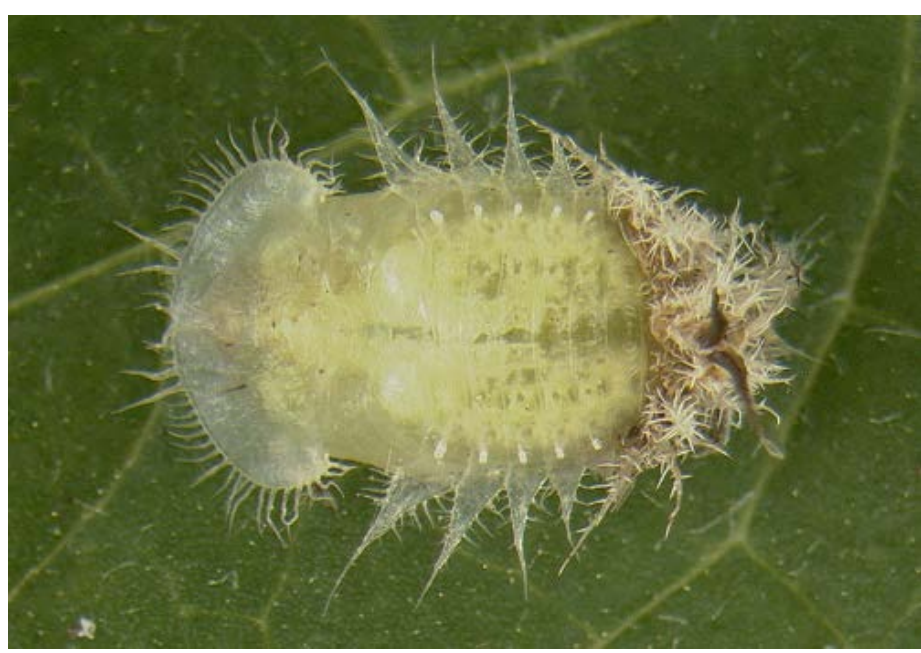

Figure 5. Pupa of Gratiana boliviana. Credit: Rodrigo Diaz, University of Florida. 


\section{Adults}

Adults are about $6 \mathrm{~mm}(1 / 4$ ") long and 4 to $5 \mathrm{~mm}$ wide. The coloration of reproductive adults is deep green whereas that of adults in diapause (overwintering stage) is pale brown.

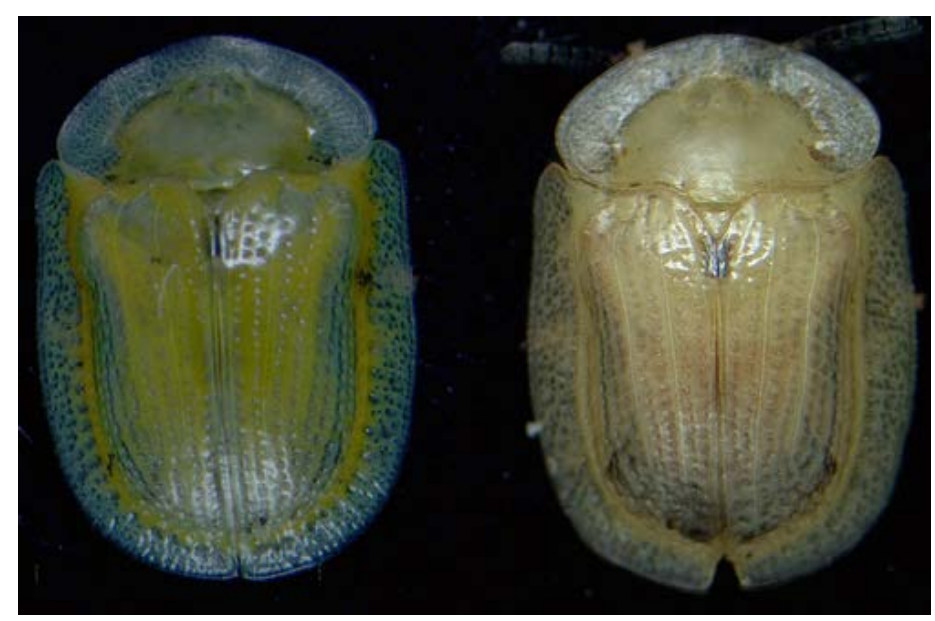

Figure 6. Reproductive adult (left) and adult in diapause (right) of Gratiana boliviana. Credit: Rodrigo Diaz, University of Florida.

Reproductive males and females can be distinguished by examination of the ventral side of the posterior abdomen. Two orange testes are visible through the integument of males, whereas white oviducts can be seen in females.

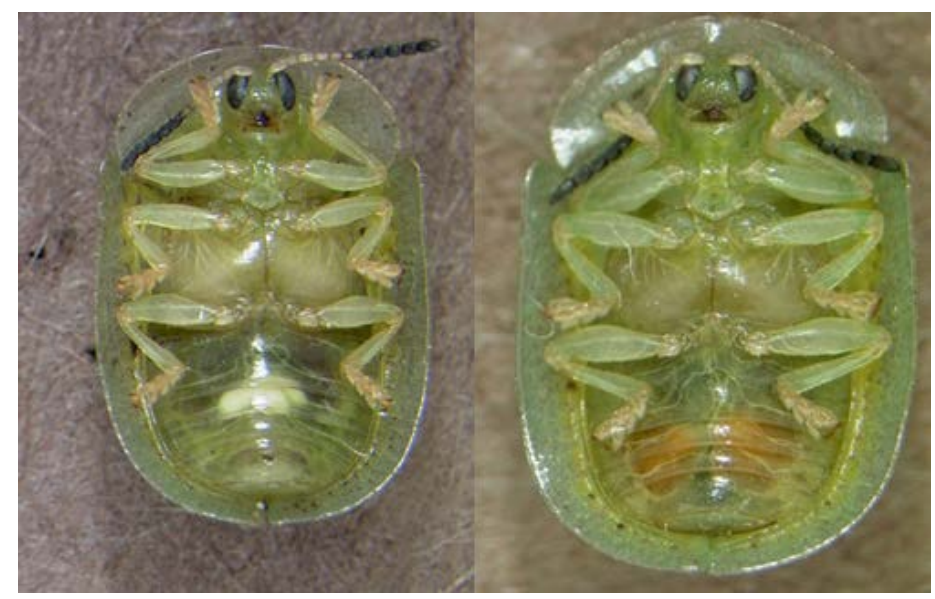

Figure 7. Female (left) and male (right) Gratiana boliviana; note paired white oviducts and orange testes. Credit: Rodrigo Diaz, University of Florida.

\section{Life Cycle, Biology, and Ecology}

Females lay eggs individually on young leaves of tropical soda apple. Larvae hatch in 5 to 6 days and feed aggressively on the leaves. There are five instars, and after 16 to 18 days, mature larvae molt to the pupal stage. Pupae are found on the underside of leaves, and this stage lasts for 6 to 7 days. The total development time from egg to adult is between 29 to 31 days at $25^{\circ} \mathrm{C}\left(77^{\circ} \mathrm{F}\right)$.
In Florida, Gratiana boliviana actively feeds and reproduces from March/April until October/November and during these months can complete 7 to 8 generations. From December to early March, adults are in a reproductive diapause (resting stage), this allows them to survive periods of cold temperature and food scarcity. They are difficult to locate during the winter, as they hide in leaf litter beneath plants.

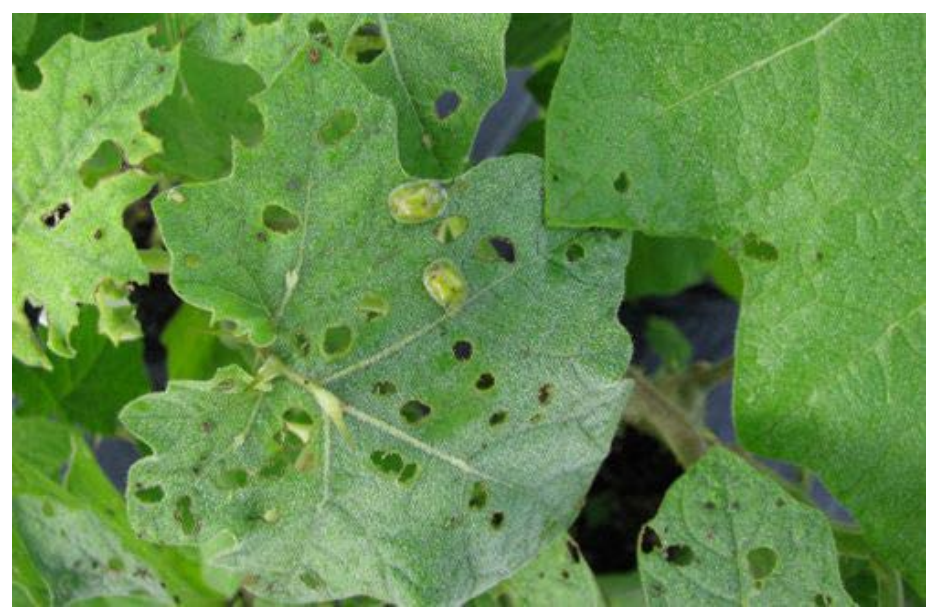

Figure 8. Tropical sodaapple leaves showing the shotgun hole damage by Gratiana boliviana. Credit: Rodrigo Diaz, University of Florida.

Natural enemies of Gratiana boliviana in Florida include predators, parasitoids, and diseases. Common predators are the bugs Geocoris punctipes (Say) (Lygaeidae), Sinea sp. (Reduviidae), Perillus bioculatus (Fabricius), Stiretrus anchorago (Fabricius) (Pentatomidae), Tupiocoris notatus (Distant) (Miridae), the fire ant Solenopsis invicta Buren (Formicidae), and the spider Peucetia viridans (Hentz) (Oxyopidae). Parasitoids reared from pupae of Gratiana boliviana include Conura side (Walker) (Chalcidae), Brasema sp. (Eupelmidae), and Aprostocetus nr. cassidis (Eulophidae); no egg or larval parasitoids have been found. Diseases recovered from larvae of Gratiana boliviana include Nosema sp. (Microspora: Nosematidae), Mattesia oryzaephili Ormiéres (Neogregarinorida: Lipotrophidae), and a gram-negative bacterium. Despite the presence of these enemies, populations of Gratiana boliviana are able to increase rapidly during summer months in central and south Florida.

\section{Host}

The only host of Gratiana boliviana in Florida is tropical soda apple, Solanum viarum. 


\section{Economic Importance}

Feeding damage by larvae and adults of Gratiana boliviana is characterized by a distinctive 'shotgun' hole pattern on leaves and is apparent from April to November. This damage not only reduces the photosynthetic area of the leaves but also creates wounds that may facilitate attack by plant diseases. These cumulative stresses hinder the growth and reproduction of tropical soda apple. By reducing the competitive ability of the weed, Gratiana boliviana indirectly facilitates the recovery of pasture grasses and native vegetation.

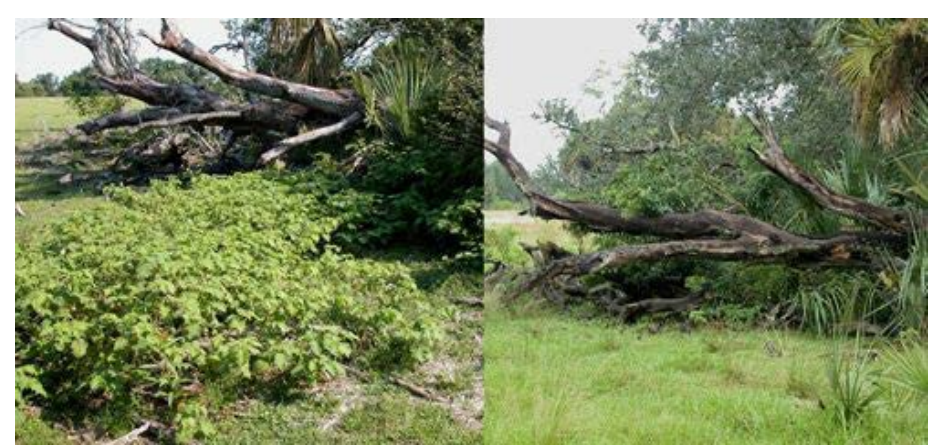

Figure 9. Pasture before and after the release of Gratiana boliviana, St. Lucie Co., Florida. Credit: William A. Overholt, University of Florida.

Studies in central Florida pastures showed that Gratiana boliviana can drastically reduce the density of tropical soda apple in less than one year after release, although it may take longer at certain locations. Gratiana boliviana will not eliminate the weed from an infested area but will reduce tropical soda apple density to a more tolerable level. In certain cases, the biological control may need to be supplemented with herbicides and mowing, especially during the winter months when beetles are not active, and in north Florida where the impact of the beetle is low.

\section{Selected References}

Diaz R, Overholt WA, Samayoa A, Sosa F, Cordeau D, Medal J. 2008. Temperature-dependent development, cold tolerance, and potential distribution of Gratiana boliviana (Coleoptera: Chrysomelidae), a biological control agent of tropical soda apple, Solanum viarum (Solanaceae). Biocontrol Science and Technology 18: 193-207.

Diaz R, Overholt WA, Hahn D, Samayoa A. 2011. Diapause induction in Gratiana boliviana (Coleoptera: Chrysomelidae), a biological control agent of tropical soda apple in Florida. Annals of the Entomological Society of America 103: 1319-1326.

Diaz R, Aguirre C, Wheeler GS, Lapointe SL, Rosskopf E, Overholt WA. 2011. Differential performance of tropical soda apple and its biological control agent Gratiana boliviana (Coleoptera: Chrysomelidae) in open and shaded habitats. Environmental Entomology 40:1437-1447.

Diaz R, Hibbard K, Samayoa A, Overholt WA. 2012. Arthropod community associated with tropical soda apple and natural enemies of Gratiana boliviana (Coleoptera: Chrysomelidae) in Florida. Florida Entomologist 95: 228-232.

Medal JC, Bustamante N, Overholt W, Diaz R, Stansly P, Amalin D, Roda A, Hibbard K, Sellers B, Hight S, Cuda JP. 2003 (revised 2011). Biology of Gratiana boliviana, the first biocontrol agent released to control tropical soda apple in the USA. Florida Cooperative Extension Service, UF/IFAS, EDIS, ENY-826 (IN487).

Medal J, Overholt W, Charudattan R, Mullahey J, Gaskala R, Diaz R, Cuda J. 2012. Tropical soda apple management plan. UF/IFAS and FDACS/DPI, Gainesville FL.

Overholt WA, Diaz R, Hibbard K, Roda AL, Amalin D, Fox AJ, Hight SD, Medal JC, Stansly PA, Carlisle B, Walter JH, Hogue PJ, Gary LA, Wiggins, LF, Kirby CL, Crawford SC. 2009. Releases, distribution and abundance of Gratiana boliviana (Coleoptera: Chrysomelidae), a biological control agent of tropical soda apple (Solanum viarum, Solanaceae) in Florida. Florida Entomologis 92: 450-457.

Overholt WA, Diaz R, Markle L, Medal JC. 2010. The effect of Gratiana boliviana (Coleoptera: Chrysomelidae) herbivory on growth and population density of tropical soda apple (Solanum viarum) in Florida. Biocontrol Science and Technology 20: 791-807. 